\title{
ANALISIS EFEKTIVITAS DAN KONTRIBUSI PENAGIHAN PAJAK SECARA AKTIF TERHADAP TUNGGAKAN PAJAK PADA KPP PRATAMA BITUNG
}

\author{
Handri Hanny Budiman ${ }^{1}$ \\ Jantje J. Tinangon ${ }^{2}$ \\ Stanley W. Alexander ${ }^{3}$ \\ Jurusan Ekonomi, Fakultas Ekonomi dan Bisnis, Universitas Sam Ratulangi, Manado, 95115, Indonesia \\ Email: ${ }^{1}$ handry.budiman@yahoo.com
}

\begin{abstract}
Effective tax collection is an appropriate means to achieve the maximum tax revenue target. The goals of study is to determining the effectiveness and contribution of active tax billing actions which includes the warning leter, forced letter, and seizure letter to disbursement of tax arrears in Tax Office Pratama Bitung during 20132014. The type of research used in this study is a descriptive study with approach case study. Data collected through interviews and documentation. The results of the study indicate that the effectiveness of tax billing rate is still not effective and the contribution of active tax billing actions to disbursement of tax arrears is still lacking. The factors is a lack of public awareness, taxpayer compliance in paying his tax debt and less optimal active tax collection process.
\end{abstract}

Keyword : Tax Debt, Taxpayer compliance, Warning Letter, Forced Letter, Seizure Letter

\section{PENDAHULUAN}

\section{Latar Belakang}

Pengertian pajak secara umum adalah suatu iuran wajib dari penduduk atau masyarakat yang dibayarkan kepada negara yang mana iuran tersebut berdasarkan undang-undang yang berlaku, pemungutannya atau pelaksanaannya dapat dipaksakan, pihak yang membayar tidak mendapat imbalan secara langsung, serta hasilnya digunakan untuk penyelenggaraan pemerintah dan pembangunan nasional.

Sistem punggutan pajak yang di anut oleh Indonesia yaitu system selfassessment berdasarkan UU No. 28 Tahun 2007 tentang Ketentuan Umum dan Tata Cara Perpajakan khususnya ayat 1 dan 2. Berdasarkan ketentuan tersebut, maka Wajib Pajak wajib untuk melakukan kegiatan menghitung, membayar dan melapor kewajiban pajakya sendiri, sehingga tidak menutup kemungkinan terjadinya pelanggaran-pelanggaran yang dilakukan oleh wajib pajak dalam melakukan kewajiban perpajakannya.Salah satu pelanggaran yang mungkin terjadi adalah keengganan untuk membayar kewajiban pajak terutangnya, sehingga menimbulkan tunggakan pajak.Tunggakan pajak timbul ketika fiskus menerbitkan Surat Ketetapan Pajak. Berdasarkan sistem self assessment yang dianut oleh Indonesia, jika suatu peristiwa, keadaan, atau perbuatan (tatbestand) yang menyebabkan terjadinya tunggakan pajak seperti tidak membayar pajak, maka saat itu juga wajib pajak memiliki tunggakan pajak, tanpa harus menunggu fiskus menerbitkan Surat Ketetapan Pajak.

Penagihan pajak yang efektif merupakan sarana yang tepat untuk mencapai target penerimaan pajak yang maksimal.Pada penagihan pajak secara aktif, langkah awal yang dilakukan fiskus yaitu menerbitkan Surat Teguran. Penerbitan surat teguran dilakukan dimana STP, SKPKB, SKPKBT belum juga dilunasi hingga melewati 7 (tujuh) hari dari batas waktu jatuh tempo.

\section{Tujuan Penelitian}

Tujuan penelitian ini adalah mengetahui tingkat efektivitas penagihan pajak aktif sebagai upaya pencairan tunggakan pajak dan tingkat kontribusi penagihan pajak aktif terhadap penerimaan pajak total.

\section{TINJAUAN PUSTAKA}

\section{Pengertian Pajak}

Pajak adalah iuran kepada negara (yang dapat dipaksakan) yang terutang oleh yang wajib membayarnya menurut peraturan-peraturan, dengan tidak mendapat prestasi kembali, yang langsung dapat ditunjuk, dan yang 
gunanya adalah untuk membiayai pengeluaran-pengeluaran umum berhubung dengan tugas negara yang menyelenggarakan pemerintahan.

Berikut ini terdapat beberapa pengertian yang diungkapkan oleh beberapa ahli, antara lain sebagai berikut :

1. Menurut Adriani yang dikutip oleh Waluyo (2011:2)

"Pajak adalah iuran kepada negara (yang dapat dipaksakan) yang terutang oleh yang wajib membayarnya menurut peraturan-peraturan, dengan tidak mendapat prestasi kembali, yang langsung dapat ditunjuk, dan yang gunanya adalah untuk membiayai pengeluaran-pengeluaran umum berhubung dengan tugas negara yang menyelenggarakan pemerintahan".

2. Menurut Feldmann dalam buku De Over Heidsmiddelen Van (terjemahan) yang dikutip oleh Waluyo (2011:2) "Pajak adalah prestasi yang dipaksakan sepihak oleh dan terutang kepada pengusaha (menurut normanorma yang ditetapkannya secara umum), tanpa adanya kontraprestasi, dan semata-mata digunakan untuk menutup pengeluaran-pengeluaran umum.

3. Menurut Soemitro yang dikutip oleh Mardiasmo (2007:2)

"Pajak adalah iuran rakyat pada kas negara berdasarkan Undang-undang (yang dapat dipaksakan) dengan tidak mendapat jasa timbal (kontraprestasi) yang langsung dapat ditunjukkan dan yang digunakan untuk membayar pengeluaran umum”.

\section{Penagihan Pajak}

Penagihan Pajak adalah serangkaian tindakan agar Penanggung Pajak melunasi utang pajak dan biaya penagihan pajak dengan menegur atau memperingatkan, melaksankan penagihan seketika dan sekaligus, memberitahukan Surat Teguran, Surat Paksa, mengusulkan pencegahan, melaksanakan penyitaan, melaksanakan penyanderaan, menjual barang yang telah disita (Kurniawan \& Pamungkas, 2006:1).

\section{Penagihan Pajak Dengan Surat Teguran}

Menurut Rudy Suhartono dan Wirawan B Iiyas (KUP) Penerbitan surat teguran, Surat peringatan, atau surat lain yang jenis merupakan awal tindakan penagihan pajak sehingga hal tersebut menjadi pedoman tindakan penagihan pajak berikutnya yaitu penyampaian surat paksa dan sebagainya.

\section{Penagihan Pajak Dengan Surat Paksa}

Dalam UU PPSP, dalam pasal 1 ayat (12) dan buku perpajakan, Mardiasmo (2011:128) disebutkan bahwa:" Surat Paksa adalah surat perintah membayar utang pajak dan biaya penagihan pajak."

Dari pengertian diatas, dapat dipahami bahwa Surat Paksa diterbitkan oleh pejabat yang berwenang tidak hanya untuk menagih utang pajak sesuai dengan ketentuan undang-undang pajak yang berkenan tetapi juga untuk menagih biaya yang timbul dalam rangka penagihan pajak, termasuk biaya penyampaian surat paksa.

\section{Utang Pajak}

Suandy (2008:128) menyatakan bahwa pada umumnya utang pajak timbul karena undang-undang, pemerintah dapat memaksakan pembayaran utang kepada wajib pajak. Negara dan rakyat sama sekali tidak ada perikatan yang melandasi utang itu, hak dan kewajiban negara dan rakyat juga tidak sama.

\section{Tunggakan Pajak}

Tunggakan pajak adalah pajak yang masih harus dibayar termasuk sanksi administrasi berupa bunga, denda atau kenaikan yang tercantum dalam Surat Ketetapan Pajak atau surat sejenisnya berdasarkan ketentuan Peraturan Perundang-Undangan Perpajakan. (Kurniawan \&Pamungkas,2006)

\section{Efektivitas}

Ulum (2008:199) mengemukakan bahwa pengertian efektivitas pada dasarnya berhubungan dengan pencapaian tujuan atau target kebijakan (hasil guna). Efektivitas merupakan hubungan antara keluaran dengan tujuan atau sasaran yang harus dicapai. Kegiatan operasional dikatakan efektif apabila proses kegiatan mencapai tujuan dan sasaran akhir kebijakan. 
Efektivitas penagihan pajak $=$

Efektivitas $=$

Tabel 2.1

Klasifikasi Pengukuran Efektivitas

\begin{tabular}{|c|c|}
\hline PRESENTASE & KRITERIA \\
\hline$>100 \%$ & SANGAT EFEKTIF \\
\hline $90-100 \%$ & EFEKTIF \\
\hline $80-90 \%$ & CUKUP EFEKTIF \\
\hline $60-80 \%$ & KURANG EFEKTIF \\
\hline$<60 \%$ & TIDAK EFEKTIF \\
\hline
\end{tabular}

(Sumber : Depdagri, Kemendagri No. 690.900.327 tahun 1996 dalam Velayati: 2013 dan Erwis: 2012)

\section{Kontribusi}

Kontribusi adalah sesuatu yang diberikan bersama-sama dengan pihak lain untuk tujuan biaya atau kerugian tertentu atau bersama (Guritno, 1992:76).Sedangkan dalam kamus Besar Bahasa Indonesia (2008:752) kontribusi dapat diartikan sebagai sumbang.

Menghitung kontribusi penerimaan pajak yang berasal dari pencairan tunggakan dengan rumus Rasio Penerimaan Pajak Tunggakan Pajak (RPTP): RPTP pencairan tunggakan pajak penerimaan pajak total 100\% Untuk menginterpretasikan rasio pencairan tunggakan pajak terhadap penerimaan pajak digunakan rumus sebagai berikut :

RPTP $=$

Tabel 2.2

Klasifikasi Kriteria Kontribusi

\begin{tabular}{|c|c|}
\hline PRESENTASE & KRITERIA \\
\hline $\mathbf{0 , 0 0 \% - 1 0 \%}$ & SANGAT KURANG \\
\hline $\mathbf{1 0 , 1 0 \% - 2 0 \%}$ & KURANG \\
\hline $\mathbf{2 0 , 1 0 \% - 3 0 \%}$ & SEDANG \\
\hline $\mathbf{3 0 , 1 0 \% - 4 0 \%}$ & CUKUP BAIK \\
\hline $\mathbf{4 0 , 1 0 \% - 5 0 \%}$ & BAIK \\
\hline Diatas 50\% & SANGAT BAIK \\
\hline
\end{tabular}

(Sumber : Depdagri, Kepmendagri N0.690.900.327 tahun 1996 dalam Velayati 2013 dan Erwis 2012)

\section{METODOLOGI PENELITIAN}

\section{Jenis Penelitian}

Penelitian ini bersifat deskriptif yaitu dengan cara menggambarkan efektivitas dan kontribusi pajak berdasarkan data yang dikumpulkan mengenai Penagihan Pajak secara Aktif terhadap pencairan tunggakan pajak. Dalam penelitian ini data yang digunakan adalah data kuantitatif yang berupa angka-angka, seperti jumlah penerbitan surat teguran, surat paksa, surat perintah. Dan data kualitatif seperti struktur organisasi KPP Pratama Bitung.

Penelitian ini dilakukan di Kantor Pelayanan Pajak Pratama Bitung, yang bertempat di Jl. Raya Sam Ratulangi, Bitung Sulawesi Utara.Waktu penelitian bulan Agustus - September 2015.

Prosedur Penelitian

1. Menentukan rumusan masalah

2. Merumuskan masalah penelitian

3. Mencari informasi yang mendukung penelitian

4. Menentukan metode penelitian 
5. Memberikan saran

6. Membuat kesimpulan

\section{Populasi dan Sampel}

Berdasarkan pengertian yang ada, maka populasi yang digunakan dalam penelitian ini adalah laporan penerbitan penagihan pajak dengan surat teguran, surat paksa, surat perintah untuk pencairan/pelunasan tunggakan pajak pada seksi penagihan KPP Pratama Bitung.Sampel yang digunakan dalam penelitian ini adalah data penagihan dengan surat teguran, surat paksa, surat perintah untuk pencairan/pelunasan tunggakan pajak yang bersumber pada laporan rutin penagihan seksi penagihan KPP Pratama Bitung selama 2 tahun yaitu tahun 2013 dan 2014.

\section{Metode Pengumpulan Data}

Untuk mendapatkan data yang lebih lengkap dan akurat, maka pengumpulan data yang dilakukan peneliti adalah sebagai berikut:

1. Peninjauan langsung

Mengadakan peninjauan langsung dan mengumpulkan data secara langsung ke lapangan untuk memperoleh data yang berkaitan dengan pelaksanaan penagihan pajak aktif dengan Surat Teguran, Surat Paksa, dan Surat Perintah oleh Jurusita Pajak di KPP Pratama Bitung.

2. Interview atau Wawancara

Penulis mengumpulkan data dengan cara melakukan wawancara langsung dengan Fiskus di KPP Pratama Bitung dan bagian penagih pajak serta pihak-pihak terkait pada seksi penagihan.

\section{Definisi Operasional dan Pengukuran Variabel}

Dalam penelitian ini, peneliti memakai analisis rasio efektivitas untuk mengukur tingkat efektivitas penagihan pajak dengan surat teguran, surat paksa, surat perintah melakukan penyitaan dan analisis rasio kontribusi untuk mengetahui apakah penerimaan tunggakan pajak cukup signifikan, maka perlunya dijabarkan pengertian operasional variabelnya.

Jadi, keseluruhan judul yang dimaksud adalah menghitung tingkat efektivitas dan penerimaan kontribusi pajak dengan menggunakan analisis rasio efektivitas dan analisis rasio kontribusi.

\section{Metode Analisis}

Metode analisis yang digunakan dalam penulisan skripsi ini adalah metode deskriptif.Metode deskripsi adalah suatu analisis yang mengumpulkan data dan menyusun data, mengolah data, dan menganalisis data angka, agar dapat memberikan gambaran mengenai sesuatu keadaan tertentu sehingga dapat di tarik suatu kesimpulan.

\section{PEMBAHASAN}

\section{Gambaran Umum Objek Penelitian}

KPP Pratama Bitung adalah lembaga pemerintahan yang bergerak dibidang pelayanan perpajakan, KPP Pratama Bitung merupakan salah satu kantor cabang Dirjen Pajak Depertemen Keuangan. Sejak tahun 2002, Dirjen Pajak melakukan reformasi birokrasi dan menjadi instansi percontohan reformasi birokrasi dalam memberikan pelayanan prima dan lekasanaan good governance mengingat kedudukan DJP sebagai instansi yang sangat strategis.Diharapkan setelah reformasi birokrasi berlangsung, penerimaan pajak dapat memberikan kontribusi pada penerimaan APBN hingga mendekati 100\% (Majalah Berita Pajak Vol. XXXIX No. 1591, 15 Juli 2007). Dengan demikian syarat mutlak menuju kemandirian bangsa adalah dengan meningkatkan peran serta aktif seluruh masyarakat melalui pembayaran pajak. KPP Pratama Bitung adalah salah satu kantor pelayanan pajak modern yang ada di provinsi Sulawesi Utara yang diresmikan tanggal 24 November 2008 yang dibentuk dari gabungan KPP Manado, kantor pelayanan pajak bumi dan bangunan manado, dan kantor pelayanan pajak bumi dan bangunan Amurang serta kantor pemeriksaan pajak Manado. KPP Pratama Bitung mempunyai wilayah kerja 1 kota dan 2 kabupaten yaitu Kota Bitung, Kab. Minahasa dan Kab. Minahasa Utara.

\section{Analisis Efektivitas}

Analisis yang digunakan untuk menghitung apakah penagihan penerimaan pajak terhadap pencairan tunggakan pajak dengan surat teguran, surat paksa, dan surat perintah melaksanakan penyitaan di KPP Pratama Bitung berdasarkan ketetapan pajak apakah efektif atau kurang efektif. 


\section{Pembahasan}

Efektivitas Penagihan Pajak dengan Surat Teguran

Data realisasi penerimaan pajak dari penerbitan surat teguran di Kantor Pelayanan Pajak Pratama Bitung tahun 2013 dan 2014 dapat dilihat pada tabel 4.7 berikut ini :

Tabel 3

Realisasi Pembayaran Surat Teguran di KPP Bitung untuk Pengukuran Efektivitas Tahun 2013-2014

\begin{tabular}{|c|c|c|c|c|}
\hline Tahun & \multicolumn{2}{|c|}{ Surat Teguran Terbit } & \multicolumn{2}{c|}{ Surat Teguran Bayar } \\
\hline 2013 & 373 & Rp. 16.750.250.250 & 93 & Rp.3.649.602.500 \\
\hline 2014 & 176 & Rp. 10.769.186.864 & 132 & Rp. 6.901.264.588 \\
\hline
\end{tabular}

Sumber: data olahan

Berdasarkan Tabel 4.7 diatas, berikut perhitungan tingkat Efektivitas penerimaan pajak dari pembayaran surat teguran tahun 2013-2014.

Efektivitas Tahun $2013($ nominal $)=$

$=\mathbf{2 1 . 7 8 \%}$

Efektivitas Tahun 2013 (Lembar) =

Efektivitas Tahun $2014($ nominal $)=$

$=64.08 \%$

Efektivitas Tahun 2014 (Lembar) $=$

$75 \%$

Tabel 4

Efektivitas Penerimaan Pajak Dengan Surat Teguran Di KPP Pratama Bitung 2013-2014

\begin{tabular}{|c|c|c|c|c|c|c|}
\hline \multirow{2}{*}{ Tahun } & \multicolumn{2}{|c|}{ Surat Teguran Terbit } & \multicolumn{2}{c|}{ Surat Teguran Bayar } & \multicolumn{2}{c|}{ Tingkat Efektivitas } \\
\cline { 2 - 7 } & Lembar & Nominal (Rp) & Lembar & Nominal (Rp) & Lembar & $\begin{array}{c}\text { Nominal } \\
(\mathbf{R p )}\end{array}$ \\
\hline 2013 & 373 & 16.750 .250 .250 & 93 & 3.649 .602 .500 & $24.93 \%$ & $21.78 \%$ \\
\hline 2014 & 176 & 10.769 .186 .846 & 132 & 6.901 .264 .588 & $75 \%$ & $64.08 \%$ \\
\hline
\end{tabular}

Sumber : Data olahan

Berdasarkan tabel 4.8 ditinjau dari segi nilai nominalnya, pembayaran Surat Teguran pada tahun 2013. Tingkat efektivitas penagihan pajak melalui surat teguran terbesar di tahun 2013 dilihat dari jumlah lembarnya memiliki presentase efektivitas $24.93 \%$ dan dari nominalnya memiliki persentase $21.78 \%$ atau pada kriteria tidak efektif. Pada tahun 2014 persentase efektivitas menunjukan adanya sedikit peningkatan mencapai persentase $60-80 \%$ dari tahun sebelumnya dilihat dari jumlah lembarnya memiliki presentase $75 \%$ dan dari nominalnya memiliki persentase $64.08 \%$ atau pada kriteria kurang efektif. Hasil perhitungan efektivitas penagihan secara aktif melalui surat teguran pada tahun 2013-2014 belum bisa dinyatakan efektif karena persentase minimal efektivitas dinyatakan cukup efektif adalah $80 \%-90 \%$.

Berdasarkan data pada KPP Pratama Bitung terlihat bahwa 2 Tahun terakhir, realisasi pencairan tunggakan pajak melalui surat teguran di KPP Pratama Bitung tidak mencapai target yang ditetapkan.

Efektivitas Penagihan Pajak dengan Surat Paksa

Data realisasi penerimaan pajak dari penerbitan surat paksa di Kantor Pelayanan Pajak Pratama Bitung tahun 2013 dan 2014 dapat dilihat pada tabel 5 berikut ini :

Tabel 5

Realisasi Pembayaran Surat Paksa di KPP Bitung Untuk Pengukuran Efektivitas Tahun 2013-2014

\begin{tabular}{|c|c|c|c|c|}
\hline Tahun & \multicolumn{2}{|c|}{ Surat Paksa Terbit } & \multicolumn{2}{c|}{ Surat Paksa Bayar } \\
\hline 2013 & 256 & Rp. 9.752.526.000 & 211 & Rp. 7.561.235.750 \\
\hline 2014 & 143 & Rp. 7.361.956.452 & 124 & Rp. 2.793.566.151 \\
\hline
\end{tabular}

Sumer: data diolah 
Berdasarkan Tabel 4.9 diatas, berikut perhitungan tingkat Efektivitas penerimaan pajak dari pembayaran surat paksa tahun 2013-2014.

$=\mathbf{7 7 . 5 3 \%}$

Efektivitas Tahun 2013 (Lembar) = -

Efektivitas Tahun $2014($ nominal $)=$

$=\mathbf{3 7 . 9 4 \%}$

Efektivitas Tahun 2014 (Lembar) =-

Tabel 6

Efektivitas Penerimaan Pajak Dengan Surat Paksa di KPP Pratama Bitung 2013-2014

\begin{tabular}{|c|c|c|c|c|c|c|}
\hline \multirow{2}{*}{ Tahun } & \multicolumn{2}{|c|}{ Surat paksa Terbit } & \multicolumn{2}{c|}{ Surat Paksa Bayar } & \multicolumn{2}{c|}{ Tingkat Efektivitas } \\
\cline { 2 - 7 } & Lembar & Nominal (Rp) & Lembar & Nominal (Rp) & Lembar & $\begin{array}{c}\text { Nominal } \\
(\mathbf{R p})\end{array}$ \\
\hline 2013 & 256 & 9.752 .526 .000 & 211 & 7.561 .235 .750 & $82.42 \%$ & $77.53 \%$ \\
\hline 2014 & 143 & 7.361 .956 .452 & 124 & 2.793 .566 .151 & $86.71 \%$ & $37.94 \%$ \\
\hline
\end{tabular}

Sumber : Data Olahan

Berdasarkan tabel 6 ditinjau dari segi nilai nominalnya, pembayaran Surat Paksa pada tahun 2013. Tingkat penerbitan Surat paksa dilihat dari jumlah lembar memiliki presentase efektivitas $82.42 \%$ dan dari nominalnya memiliki persentase $77.53 \%$ atau pada kriteria cukup efektif. Pada tahun 2014 persentase efektivitas lembar yang meningkat dengan nominal yang menurun mencapai persentase terendah dari tahun sebelumnya dilihat dari jumlah lembarnya memiliki presentase $86.71 \%$ dan dari nominalnya memiliki persentase $37.94 \%$ atau pada kriteria cukup efektif di karenakan jumlah lembar yang dikembalikan lebih tinggi dari pada jumlah nominal. Hasil perhitungan efektivitas penagihan secara aktif melalui surat teguran pada tahun 2013-2014 bisa dinyatakan efektif karena persentase minimal efektivitas dinyatakan cukup efektif adalah 80\%-90\%.

\section{Efektivitas Penagihan Pajak dengan Surat Perintah Penyitaan}

Data realisasi penerimaan pajak dari penerbitan surat perintah melaksanakan penyitaan di Kantor Pelayanan Pajak Pratama Bitung tahun 2013 dan 2014 dapat dilihat pada tabel 7 berikut ini :

Tabel 7

Realisasi Pembayaran Surat Perintah Melaksanakan Penyitaan di KPP Bitung Untuk Pengukuran Efektivitas Tahun 2013-2014

\begin{tabular}{|c|c|c|c|c|}
\hline Tahun & \multicolumn{2}{|c|}{ SPMP Terbit } & \multicolumn{2}{c|}{ SPMP Bayar } \\
\hline 2013 & 3 & Rp. 465.750.200 & 3 & Rp. 425.750.125 \\
\hline 2014 & 9 & Rp. 3.250.630.025 & 7 & Rp. 450.075.200 \\
\hline
\end{tabular}

Sumber: data diolah

Berdasarkan Tabel 7 diatas, berikut perhitungan tingkat Efektivitas penerimaan pajak dari pembayaran SPMP tahun 2013-2014.

Efektivitas Tahun 2013( nominal)

Efektivitas Tahun 2013 (Lembar) =-

Efektivitas Tahun $2014($ nominal $)=$

Efektivitas Tahun 2014 (Lembar) =-

$$
=91.41 \%
$$$$
=13.84 \%
$$ 
Tabel 8

Efektivitas Penerimaan Pajak Dengan Surat Perintah Melaksanakan Penyitaan

Di KPP Pratama Bitung 2013-2014

\begin{tabular}{|c|c|c|c|c|c|c|}
\hline \multirow{2}{*}{ Tahun } & \multicolumn{2}{|c|}{ SPMP Terbit } & \multicolumn{2}{c|}{ SPMP Bayar } & \multicolumn{2}{c|}{ Tingkat Efektivitas } \\
\cline { 2 - 7 } & Lembar & Nominal (Rp) & Lembar & Nominal (Rp) & Lembar & $\begin{array}{c}\text { Nominal } \\
(\mathbf{R p})\end{array}$ \\
\hline 2013 & 3 & 465.750 .200 & 3 & 425.750 .125 & $100 \%$ & $91.41 \%$ \\
\hline 2014 & 9 & 3.250 .630 .025 & 7 & 450.075 .200 & $77.77 \%$ & $13.84 \%$ \\
\hline
\end{tabular}

Sumber : Data diolah

Berdasarkan tabel 8 ditinjau dari segi nilai nominalnya, pembayaran Surat Perintah Melaksanakan Penyitaan pada tahun 2013. Tingkat penerbitan SPMP dilihat dari jumlah lembar memiliki presentase efektivitas $100 \%$ dan dari nominalnya memiliki persentase $91.41 \%$ atau pada jumlah lembar kriteria sangat efektif sedangkan pada nominalnya kriteria efektif. Pada tahun 2014 persentase efektivitas yang menurun dari tahun sebelumnya dilihat dari jumlah lembarnya memiliki presentase $77.77 \%$ dan dari nominalnya memiliki persentase $13.84 \%$ atau pada jumlah lembarnya pada kriteria kurang efektif dan dari jumlah nominalnya pada kriteria tidak efektif. Hasil perhitungan efektivitas penagihan secara aktif melalui SPMP pada tahun 2013-2014 belum bisa dinyatakan efektif karena persentase dari tahun sebelumnya lebih baik di bandingkan dengan tahun sesudahnya.

Apabila melihat tingkat efektivitas pada tahun 2014 dan di bandingkan dengan tahun 2013, maka pencapaian target pada tahun 2013 yang realisasinya sangat melebihi target yang ditetapkan dibandingkan dengan tahun sesudahnya.

\section{Kontribusi Penagihan Pajak Secara Aktif melalui Surat Teguran}

Tabel 9

Hasil Perhitungan Kontribusi Penagihan Pajak Secara Aktif Melalui Surat Teguran Tahun 2013-2014 Di KPP Pratama Bitung

\begin{tabular}{|c|c|c|c|c|}
\hline Tahun & Realisasi & Penerimaan total & Kontribusi & Kriteria \\
\hline 2013 & Rp.3.649.602.500 & Rp. 16.145.125.310 & $22,61 \%$ & Sedang \\
\hline 2014 & Rp. 6.901.264.588 & Rp. 9.750.081.945 & $70,78 \%$ & Sangat Baik \\
\hline
\end{tabular}

Sumber : Data diolah

Berdasarkan tabel 9, pencairan tunggakan pajak dengan surat teguran terhadap penerimaan pajak di KPP Pratama Bitung di Tahun 2013 mempunyai tingkat kontribusi sebesar 22,61\%. Nilai tersebut didapat berdasarkan perhitungan pencairan tunggakan pajak dengan surat teguran sebesar Rp. 3.649.602.500 dengan penerimaan pajak total yang sebesar Rp. 16.145.125.310. Nilai Kontribusi di tahun ini tergolong kriteria sedang dalam penerimaan pajak total di KPP Pratama Bitung.

Pada tahun 2014, nilai kontribusinya meningkat yaitu sebesar 70.78\%.Nominal pencairan tunggakan pajak Rp 6.901.264.588 dengan penerimaan pajak total sebesar Rp. 9.750.081.945.Nilai kontribusi di tahun ini tergolong kriteria sangat baik dalam penerimaan pajak total di KPP Pratama Bitung.

\section{Kontribusi Penagihan Pajak Secara Aktif melalui Surat Paksa}

Tabel 10

Hasil Perhitungan Kontribusi Penagihan Pajak Secara Aktif Melalui Surat Paksa Tahun 2013-2014 di KPP Pratama Bitung

\begin{tabular}{|c|c|c|c|c|}
\hline Tahun & Realisasi & Penerimaan total & Kontribusi & Kriteria \\
\hline 2013 & Rp. 7.561.235.750 & Rp. 34.559 .753 .032 & $21,88 \%$ & Sedang \\
\hline 2014 & Rp. 2.793 .566 .151 & Rp. 21.065.712.355 & $13,26 \%$ & Kurang \\
\hline
\end{tabular}

Sumber : Data diolah

Berdasarkan tabel 10, pencairan tunggakan pajak dengan surat paksa terhadap penerimaan pajak di KPP Pratama Bitung di Tahun 2013 mempunyai tingkat kontribusi sebesar 21,88\%. Nilai tersebut didapat berdasarkan perhitungan pencairan tunggakan pajak dengan surat teguran sebesar Rp. 7.561.235.750 dengan 
penerimaan pajak total yang sebesar Rp. 34.559.753.032. Nilai Kontribusi di tahun ini tergolong kriteria sedang dalam penerimaan pajak total di KPP Pratama Bitung.

Pada tahun 2014, nilai kontribusinya menurun yaitu sebesar 13.26\%.Nominal pencairan tunggakan pajak Rp. 2.793.566.151 dengan penerimaan pajak total sebesar Rp. 21.065.712.355.Nilai kontribusi di tahun ini tergolong kriteria kurang dalam penerimaan pajak total di KPP Pratama Bitung.

Kontribusi penagihan melalui surat paksa terhadap penerimaan pajak dapat dinilai kurang karena seluruh hasil perhitungan tahun 2013-2014 menunjukan penurunan penerimaan atau dengan dengan kriteria kurang.

Tabel 11

Hasil Perhitungan Kontribusi Penagihan Pajak Secara Aktif Melalui Surat Perintah Melaksanakan Penyitaan Tahun 2013-2014 di KPP Pratama Bitung

\begin{tabular}{|c|c|c|c|c|}
\hline Tahun & Realisasi & Penerimaan total & Kontribusi & Kriteria \\
\hline 2013 & Rp. 425.750 .125 & Rp. 1.879 .325 .415 & $22.65 \%$ & Sedang \\
\hline 2014 & Rp. 450.075 .200 & Rp. 2.115 .481 .310 & $21.27 \%$ & Sedang \\
\hline
\end{tabular}

Sumber : Data diolah

Berdasarkan tabel 11, pencairan tunggakan pajak dengan surat perintah melaksanakan penyitaan terhadap penerimaan pajak di KPP Pratama Bitung di Tahun 2013 mempunyai tingkat kontribusi sebesar 22,65\%. Nilai tersebut didapat berdasarkan perhitungan pencairan tunggakan pajak dengan surat teguran sebesar Rp. 425.750.125 dengan penerimaan pajak total yang sebesar Rp. 1.879.325.415. Nilai Kontribusi di tahun ini tergolong kriteria sedang dalam penerimaan pajak total di KPP Pratama Bitung.

Pada tahun 2014, nilai kontribusinya meningkat yaitu sebesar 21,27\%. Nominal pencairan tunggakan pajak Rp. 450.075.200 dengan penerimaan pajak total sebesar Rp. 2.115.481.310.Nilai kontribusi di tahun ini tergolong kriteria sedang dalam penerimaan pajak total di KPP Pratama Bitung.

\section{Hasil Perhitungan Penagihan Pajak Secara Aktif}

Hasil Perhitungan kesulurahan efektivitas penagihan pajak secara aktif yang meliputi surat teguran, surat paksa, dan SPMP disajikan pada tabel 4.16.

Tabel 12

Hasil Perhitungan Efektivitas Penagihan Pajak Secara Aktif

\begin{tabular}{|c|c|c|c|c|}
\hline Jenis surat & 2013 & Kriteria & 2014 & Kriteria \\
\hline Surat Teguran & 21.78 & Tidak efektif & 64.08 & Kurang efektif \\
\hline Surat Paksa & 77.53 & Cukup efektif & 37.94 & Tidak Efektif \\
\hline SPMP & 91.41 & Efektif & 13.84 & Tidak Efektif \\
\hline
\end{tabular}

Sumber : data diolah

Berdasarkan tabel 12 dapat diketahui bahwa efektivitas penagihan pajak secara aktif di KPP Pratama Bitung selama tahun 2013 yang meliputi penagihan dengan surat teguran, surat paksa, dan SPMP cenderung meningkat. Sedangkan pada tahun 2014 yang meliputi penagihan dengan surat teguran, surat paksa, SPMP cenderung menurun. Hal ini terbukti pada tahun 2013 dapat kita lihat dari surat teguran sampai dengan SPMP terjadinya peningkatan. Pada tahun 2014 penagihan pajak secara aktif dapat dinyatakan kurang efektif pada surat teguran, dan tidak efektif pada surat paksa dan SPMP.

\section{Hasil Perhitungan Kontribusi Penagihan Pajak Secara Aktif}

Hasil Perhitungan kesulurahan kontirbusi penagihan pajak secara aktif yang meliputi surat teguran, surat paksa, dan SPMP disajikan pada tabel 4.17.

Tabel 4.17

Hasil Perhitungan Kontribusi Penagihan Pajak Secara Aktif

\begin{tabular}{|c|c|c|c|c|}
\hline Jenis surat & 2013 & Kriteria & 2014 & Kriteria \\
\hline Surat Teguran & $22.61 \%$ & Sedang & $70.78 \%$ & Sangat baik \\
\hline Surat Paksa & $21.88 \%$ & Sedang & $13.26 \%$ & Kurang \\
\hline SPMP & $22.65 \%$ & Sedang & $21.27 \%$ & Sedang \\
\hline
\end{tabular}

Sumber : data diolah 
Berdasarkan tabel 4.17 dapat diketahui bahwa kontribusi pencairan tunggakan pajak dengan penagihan pajak secara aktif terhadap penerimaan pajak di KPP Pratama Bitung selama tahun 2013-2014. Dapat terlihat pada tahun 2013 penagihan pajak secara aktif melalui Surat teguran, surat paksa dan SPMP mempunyai kriteria Sedang. Pada tahun 2014 penagihan pajak secara aktif melalui surat teguran mempunyai kriteria sangat baik, sedangkan penagihan pajak secara aktif melalui surat paksa mempunyai kriteria sangat kurang dan SPMP mempunyai kriteria Sedang.

Menyadari bahwa kontribusi penagihan pajak secara aktif di KPP Pratama Bitung tahun 2013-2014 smemiliki kriteria sangat kurang, sangat baik, dan cukup baik, maka perlu adanya perbaikan kinerja khususnya pada bidang penagihan dalam rangka mengoptimalkan kontribusi penagihan pajak seecara aktif terhadap pencairan tunggakan pajak sehingga mampu meningkatkan peneriman pajak di KPP Pratama Bitung.

\section{KESIMPULAN DAN SARAN}

\section{Kesimpulan}

Penagihan pajak secara aktif dengan menggunakan Surat Teguran, Surat Paksa, dan SPMP pada KPP Partama Bitung pada tahun 2013 tergolong efektif atau menunjukan adanya peningkatan. Di bandingkan dengan tahun 2014 yang mengalami penurunan dari surat teguran, surat paksa dan SPMP, Penyebabnya antara Wajib Pajak lalai dalam melunasi utang pajak, tempat tinggal yang susah untuk di jangkau, atau kurangnya penyuluhan yang di lakukan sehingga masih banyak wajib pajak yang mungkin kurang memahami. Kontribusi penagihan pajak secara aktif dengan surat teguran, surat paksa, surat perintah melaksanakan penyitaan di KPP Bitung tergolong dalam kriteria Baik karena penerimaan kontribusi yang kurang dari $20 \%$ hanya terdapat pada penerimaan kontribusi dengan surat paksa di tahun 2014. Tingkat efektivitas maksimal dengan Surat perintah melaksanakan penyitaan terjadi pada tahun 2013 dan tingkat kontribusi maksimal dengan Surat teguran terjadi pada Tahun 2014. Jadi, belum tentu jika tingkat efektivitas maksimal suatu tahapan di tahun tertentu maka akan mempunyai tingkat kontribusi yang maksimal dengan tahapan dan tahun yang sama.

\section{Saran}

Berdasarkan pembahasan dan kesimpulan yang telah di uraikan terdapat beberapa saran yang dapat di berikan untuk KPP Pratama Bitung tentang penagihan pajak dengan menggunakan surat teguran, surat paksa, dan SPMP sebagai berikut:

1. KPP Pratama Bitung harus perlu memperhatikan kegiatan yang bertujuan untuk meningkatkan wawasan serta kesadaran Wajib Pajak tentang keutamaan membayar pajak.

2. Kantor Pelayanan Pajak Pratama Bitung perlu mengadakan kerja sama dengan pemerintah daerah untuk memudahkan mencari penanggung pajak yang pindah tanpa pemberitahuan.

3. Kantor Pelayanan Pajak Pratama Bitung perlu memanfaatkan perkembangan teknologi untuk kelancaran proses penagihan, misalnya alat dokumentasi sebagai bukti bahwa penanggung pajak mempunyai asset yang dapat disita.

\section{DAFTAR PUSTAKA}

Derlina, Sutria, Tunas. 2013. Analisis Efektivitas Penagihan Tunggakan Pajak Dengan Menggunakan Surat Paksa Pada Kantor Pelayanan Pajak Pratama Manado.Manado ; Program S-1 Universitas Sam Ratulangi Manado.

Devika.Korua. 2014. Analisis Efektivitas dan Kontibusi Penagihan Pajak aktif Terhadap Pencairan Tunggakan Pajak pada Kantor Pelayanan Pajak Pratama Manado.Manado : Program S-1 Universitas Sam Ratulangi Manado.

Edward, W. Memah. 2013Efektivitas dan kontribusi penerimaan pajak hotel dan restoran terhadap PAD

Kota Manado.Manado : Program S-1 Universitas Sam Ratulangi Manado.

Ilyas, Wirawan B., Burton, Richart, 2010. Hukum Pajak.Jakarta: Salemba empat

Kurniawan, Panca dan Bagus Pamungkas, 2006.Penagihan Pajak di Indonesia, Edisi Pertama, Bayumedia Publishing, Malang.

Mardiasmo, 2011.Perpajakan Edisi Revisi. Yogyakarta: Andi.

Mardiasmo, 2009.Akuntansi Sektor Publik. Yogyakarta: Andi

Mujiono, Djoko. 2010. Panduan Brevet Pajak. Yogyakarta: Andi 
Pangemanan H. R. 2013. Analisis Efektivitas dan Kontribusi Pajak BPHTB Terhadap Penerimaan Pajak Daerah Kota Manado.Jurnal Ilmiah Mahasiswa FEB Universitas Sam Ratulangi Manado.

Republik Indonesia, Undang-Undang nomor 6 tahun 1983 Tentang Ketentuan umum dan tata cara perpajakan Sebagaiman telah beberapa kali diubah terakhir dengan Undang-Undang nomor 16 tahun 2009

Republik Indonesia, Undang-undang nomor 6 tahun1997 Tentang Penagihan Pajak Dengan Surat Paksa sebagaimana telah diubah dengan undang-undang nomor 19 Tahun 2000.

Rifari.Widya.Kusumo.2013. Efektivitas Penagihan Pajak dengan Surat Paksa dan Penyitaan dalam Upaya Optimalisasi Penerimaan Pajak pada Kantor Wilayah Direktorat Jendral Pajak Jawa Timur III.Jurnal Ilmiah untuk memenuhi Gelar kesarjanaan S-1 Universitas Brawijaya Malang.

Sugiyono, 2012.Metode Penelitian Bisnis. Bandung: Alfabeta

Suandy, Erly. 2006. Perpajakan. Edisi 2. Jakarta: Salemba Empat

Siahaan, Maribot P. 2010, Pajak Daerah \& Retribusi Daerah Edisi Revisi. Jakarta: Rajawali Pers.

Wahyu, 2011.Perpajakan Indonesia. Jakarta: Salemba Empat

Waluyo, 2011.Perpajakan Indonesia.Jakarta :Salemba Empat

www.pajak.go.id/dmdocuments/PENAGIHAN

www.pajakonline.com/Dasar-Hukum-penagihan-pajak 